\title{
XIV Rules AND Regulations
}

1. The Board of Directors may prescribe such rules and regulations not inconsistent with these by-laws relating to the management and operation of the corporation as they deem expedient, provided that such rules and regulations shall have force and effect only until the next Annual Meeting of the members of the corporation when they shall be confirmed, and in default of confirmation at each Annual Meeting of members shall at and from that time cease to have force and effect.

2. In these by-laws the singular shall include the plural and the plural the singular; the masculine shall include the feminine.

IN WITNESS WHEREOF we have hereunto set our hands and affixed our seals.

\section{A. MACDONALD AND AVILA BEDARD HONOURED BY UNIVERSITY OF NEW BRUNSWICK}

Thirty-one prominent men and women were honoured by the University of New Brunswick on the occasion of its 150th anniversary being celebrated this year. The group, which included many well-known business and professional leaders and a number of outstanding alumni and several life-long friends of the university, received honorary doctor's degrees at the encaenial exercises on May 18 and 19.

Among the recipients were representatives of the arts, the sciences, the clergy, education, engineering, law and journalism. Eight heads of Canadian universities and colleges were honoured. Five of the seven speakers who appeared on the campus earlier this year to take part in the university's anniversary lecture series were included, the remaining two having already received honorary degrees from U.N.B.

Among the outstanding public servants who received the degree of doctor of laws were two well-known foresters-D. A. MacDonald, Director, Department of Resources and Development, Ottawa, and Avila Bedard, Deputy Minister of Lands and Forests, Quebec.

\section{UNIVERSITY OF NEW BRUNSWICK SCHOLARSHIPS}

The winners of the 1950 Beaverbrook Overseas Scholarships at the University of New Brunswick were announced recently. The selection committee consisted of Hon. J. B. McNair, K.C., Hon. G. P. Burchill and Dr. A. W. Trueman, president of the university, who made the announcement.

The students who were awarded the valuable scholarships are: Eleanor $G$. Wylie, Richard W. Kierstead, James M. O. Wheatley and R. Robert Ritchie, all of Fredericton; Roderick M. MacLeod and Vernon B. Copp, of Saint John; Althea A. Warren and A. Robert Rogers, of Moncton; and Harry Kalpakis and David E. Etheridge, of Montreal.

The scholarships were established in 1946 by Rt. Hon. Lord Beaverbrook, chancellor of the University of New Brunswick. They enable graduates and former students to do one year of postgraduate study at the University of London.

David Etheridge is the son of Mr. and Mrs. P. E. Etheridge, St. Eustace sur le Lac, Que. From 1939-45 Etheridge saw service with the Canadian 